\title{
Katarzyna Osior-Szot
}

\author{
Uniwersytet Warszawski
}

ORCID: 0000-0003-2417-8746

\section{Różnice w stylach komunikacyjnych kobiet i mężczyzn}

\begin{abstract}
Streszczenie
W artykule przeanalizowano, czy sposób komunikowania się za pomocą języka zależy od płci mówiącego. W tym celu przeprowadzono analizę dziesięciu mów motywacyjnych uygłaszanych przez kobiety i mężczyzn, która wykazała, że oprócz treści komunikowanych niezależnie od płci nadawcy (np. zuracanie uwagi na takie wartości, jak odwaga, talent, marzenia) istnieją wątki poruszane głównie przez kobiety (np. równowaga życiowa czy samoświadomość) oraz takie, które są charakterystyczne tylko dla mężczyzn (np. determinacja w dążeniu do celu, skuteczność działania oraz profesjonalizm). Różnice między komunikacją męską a kobiecą dotyczą także używanych słów - w mowach kobiet więcej jest uskaźników niepewności, do których należą zaimki nieokreślone (np. jakiś, gdzieś) oraz uyrażenia metatekstowe (ang. discourse markers) (np. że tak powiem, tak naprawdę, po prostu), w mowach mężczyzn przeważają nazwy wyraziste semantycznie i do tego nacechowane pozytywnie (np. sukces, mędrzec, wiedza, trener). Przeprowadzona analiza wykazała ponadto, że różnice komunikacyjne między kobietami a mężczyznami dotyczą także gramatyki. Kobiety częściej uypowiadają się u 1. os. lp. i używają głównie czasu przeszłego, a mężczyźni preferują narrację 3-osobową oraz czasy teraźniejszy i przyszły.
\end{abstract}

Słowa kluczowe: komunikacja, płeć, mowa motywacyjna, korpus tekstów.

\section{Differences in communication styles between women and men}

\begin{abstract}
The article is an attempt to check whether the way language is communicated depends on gender. For this purpose an analysis of ten motivational speeches by men and women was carried out which showed that apart from the content communicated independently of the sender's sex (e.g. paying attention to such values as courage, talent, dreams), there are threads touched mainly by women (e.g. life balance or self-awareness), and those that are characteristic only for men (e.g. determination in pursuit of goals, effectiveness of action and professionalism). Differences between men's and women's communication also apply to words being used - in women's speech there are more uncertainty indicators, which include indefinite pronouns (e.g. some, somewhere), and metatextual expressions (in English: discourse markers) (e.g. so to speak, in fact, simply), in men's speeches, semantically expressive names prevail as well as positive ones (e.g. success, sage, knowledge, and coach). The analysis also showed that the communication differences between women and men also concern grammar. Women speak more often in the first person
\end{abstract}


singular and they mainly use past tense, and men prefer third person narrative and present or future tenses.

Keywords: communication, gender, motivational speech, body of texts.

\section{Wprowadzenie}

Hasło „komunikacja międzypłciowa” nie tylko dla językoznawców może stanowić źródło fascynacji oraz dociekań intelektualnych. Już pobieżne przeszukanie zasobów internetowych ujawnia, że badanie różnic - także tych lingwistycznych - między kobietami a mężczyznami to zagadnienie żywo obecne w dyskursie społecznym. W niemal każdym tekście dostępnym w internecie na rozmaitych (mniej lub bardziej wiarygodnych) portalach przeczytamy stuierdzenia: kobiety mówią więcej, mężczyźni wolą konkrety, dla pań ważniejsze jest budowanie relacji, panowie natomiast rozmowę traktują jako walkę - i tak dalej. Pokłosie obiegowych opinii widzę także jako trener kompetencji komunikacyjnych, gdy podczas warsztatów prowadzimy z uczestnikami ożywione dyskusje o tym, czy lingwistyczne różnice międzypłcioue to coś zauważalnego uspółcześnie, czy raczej powinniśmy patrzeć na nie jak na odblaski przeszłości, a może nawet jak na ślady socjologicznej mitologii. Nie ulega za to wątpliwości, że temat budzi znaczne zainteresowanie społeczne.

Przekaz popularnonaukowy i popkulturowy w dużej mierze uległ uproszczeniu, dlatego gdy chodzi o zagadnienie komunikacji międzypłciowej, szczególnie istotne wydaje się oddzielenie ziarna od plew oraz sięgnięcie do badań naukouych, które zarówno potwierdzają niektóre obiegowe intuicje, jak i obalają hipotetyczne asymetrie. Zamierzam zatem w tym artykule zestawić istotne ustalenia teoretyczne dotyczące różnic w stylach komunikacyjnych kobiet i mężczyzn z materiałem źródłowym opracowanym przeze mnie u ramach wcześniejszych badań: z mikrokorpusem mów motywacyjnych, czyli tekstów należących do dziedziny psychologii rozwoju osobistego. Wspomniane zestawienie zacznę od krótkiej charakterystyki tekstów tworzących mój mikrokorpus, a następnie poszukam w nim cech odróżniających mowy wygłaszane przez kobiety od tych przygotowanych przez mężczyzn. W podsumowaniu zebranych uniosków wskażę natomiast, jakie aspekty istotne dla zagadnienia należałoby jeszcze zbadać, aby udzielić jak najsensouniejszej odpowiedzi na pytanie, czy każda z płci pochodzi rzeczyuiście $\mathrm{z}$ innej lingwistycznej planety.

\section{Style komunikacyjne kobiet i mężczyzn}

Rozważania dotyczące komunikacji międzypłciouej należałoby zacząć od bilansu szans i zagrożeń tkwiących w badanym zagadnieniu. Do kwestii problemouych należy już sam uybór odpowiedniej terminologii. Badacz może mieć bowiem trudności z rozstrzygnięciem, jakim terminem określić potencjalne linguistyczne niejednolitości 
płciowe ${ }^{1}$. Wspomina o tym Kwiryna Handke, zastanawiając się, czy mówimy o języku | biolekcie ${ }^{2}$ danej płci, czy raczej o stylu lub metastylu ${ }^{4}$. Warto zurócić uwagę także na przystawalność badań już poczynionych do uspółczesnych realiów życia kobiet i mężczyzn, które zmieniają się w sposób bardzo dynamiczny. Istniejące przeglądy podejść badawczych dotyczących relacji między językiem a płcią - na przykład opracowanie autorstua Zbigniewa Klocha ${ }^{5}$, przekazujące różnorodność metodologiczną w ujęciach tematu - w dużej mierze opierają się na literaturze sprzed kilkunastu lub kilkudziesięciu lat. W odniesieniu do zmian socjologicznych, związanych między innymi z rosnącą aktyunością kobiet na rynku pracy i w życiu publicznym, przemianami modelu rodziny czy promowaniem równouprawnienia płci w polityce społecznej, aktualność ustaleń teoretycznych staje się szczególnie istotna. Należy róunież pozostać świadomym dużego niebezpieczeństua stereotypizacji zagadnienia, o czym zresztą już uspominano.

Zarazem rysuje się jednak ogromny potencjał tkwiący w badaniach nad językiem kobiet i mężczyzn. Dokładniejsze przyjrzenie się zagadnieniu może pozytyunie upłynąć na uszystkie te płaszczyzny, gdzie obie płci współpracują ze sobą i potrzebują dobrego wzajemnego zrozumienia - stopień przełożenia nauki na życie codzienne jest tu naprawdę duży. Solidna analiza różnic językowych uwarunkowanych płcią może przecież uiele unieść do psychologii biznesu: może bardzo ułatwić skuteczne budowanie uspółpracy u zespole, naprawianie relacji między członkami grupy czy usprawnianie komunikacji. Styk językoznawstua i biznesu ukazuje się w tym przypadku jako szczególnie wyraźny, twórczy oraz użyteczny dla obu stron. Podobne wnioski można wyciągnąć u odniesieniu do analizowanych $\mathrm{w}$ tym artykule tekstów z zakresu psychologii rozwoju osobistego - spojrzenie na mowy motywacyjne pod kątem płci nadawcy otwiera kolejne perspektywy szukania cech charakterystycznych dla tego gatunku wypowiedzi.

Spośród wielu badań dotyczących stylów komunikacyjnych żeńskich i męskich przywołajmy tu niektóre ustalenia Kuiryny Handke ${ }^{6}$, Deborah Tannen ${ }^{7}$ i Robin Lakoff ${ }^{8}$ dotyczące charakterystycznych strategii komunikacyjnych stosowanych przez kobiety. Handke zauważa w języku kobiet pogłębioną ekspresywność, objawiającą się między innymi nadużywaniem wykrzykników, skłonnością do spieszczeń i zdrobnień oraz wyraźnym ujaunianiem stosunku emocjonalnego (połączonego z wartościowaniem)9 .

\footnotetext{
${ }^{1}$ W niniejszym artykule decyduję się na używanie terminu „styl komunikacyjny” ze uzględu na traktowanie mowy motywacyjnej jako narzędzia komunikacji z odbiorcami w celach zbudowania określonej relacji.

${ }^{2}$ K. Handke, Język a determinanty ptci, „Język a Kultura” 1994, t. 9, s. 15-29.

${ }^{3}$ Ibidem.

${ }^{4}$ K. Handke, Styl kobiecy we współczesnej polszczyźnie kolokwialnej, „Studia z Filologii Polskiej i Słouiańskiej" 1990, t. 26, s. 5-24.

5 Z. Kloch, Język i pteć: różne podejścia badawcze, „Pamiętnik Literacki” 2000, z. 1, s. 141-160.

${ }^{6}$ K. Handke, Język a determinanty..., op. cit.

7 D. Tannen, Ty nic nie rozumiesz! Kobieta i mężczyzna w rozmowie, tłum. A. Sylwanowicz, Zysk i S-ka, Poznań 1999.

${ }^{8}$ Lakoff, Language and Woman's Place, Harper \& Row, Nowy Jork 1975.

${ }^{9}$ K. Handke, Język a determinanty..., op. cit., s. 15-29.
} 
Owo zuracanie się ku urażeniom i odczuciom łączy się z tym, co Tannen określa jako dbałość kobiet o relacje poziome u społeczeństwie: według badaczki panie są nastawione przede uszystkim na uczuciowość oraz tworzenie więzi, stąd ich skłonność do takiego komunikowania się, które umożliwiałoby umacnianie serdecznych relacji. Drugą stroną medalu są według Tannen relacje pionowe kreowane przez mężczyzn, dla których cenniejsze od rozbudowanego grona znajomych byłoby uspinanie się po drabinie hierarchii społecznej. W zuiązku z tym komunikacja miałaby ich uspomagać u pozycjonowaniu się jako lider, ekspert posiadający umiejętność racjonalnej oceny rzeczywistości ${ }^{10}$.

Jak widać, wnioski Tannen sięgają daleko poza sam język, strategie komunikacyjne wyrażają bowiem sposób kreowania siebie w świecie, postrzegania własnej pozycji społecznej sprzężonej z płciowością. Idąc za tezami badaczki, moglibyśmy uysnuć wniosek: mężczyzna staje się ekspertem, natomiast kobieta widzi siebie jako mniej upoważnioną do wygłaszania zdecydowanych opinii i podejmowania jednoznacznych decyzji. Dowodzi tego Lakoff, gdy pisze, że komunikowanie się u sposób niepewny pozwala kobietom unikać sytuacji konfliktowych, a przy tym pozostawia im zawsze możliwość uycofania się ze swojego zdania. Lakoff podkreśla wyraźną obecność tak zwanych uskaźników niepeuności w komunikatach kobiet, czyli:

- $\quad$ wypowiedzi kwalifikujących (np. no wiesz..., coś w tym rodzaju..., możliwe, że...);

- wyrażeń asekuracyjnych (np. myślę..., zastanawiam się..., czuję...);

- wyrażeń zaprzeczających (np. wiem, że to głupie pytanie, ale..., moge się mylić, ale...);

- próśb złożonych (np. Czy nie poszedtbyś ze mna dziś do teatru? zamiast Pójdziesz ze mna dziś do teatru? lub Chodź ze mną dziś do teatru $)^{11}$.

Osłabienia komunikatu Lakoff upatruje również w tendencji kobiet do kończenia wypowiedzi intonacją wznoszącą lub dodatkowym pytaniem (np. Ładna dziś pogoda, prawda?), natomiast hipotezę tę podważyła Carole Edelsky, która w swoich badaniach intonację łączyła przede wszystkim z kontekstem i nie zauważyła istotnych prawidłowości uwarunkowanych płcią przy badaniu podobnych typów sytuacji ${ }^{12}$.

Reasumując - przytoczone wyniki badań sugerują, że teksty, których autorkami są kobiety, powinny charakteryzować się: zwiększoną ekspresyunością, kreowaniem nadawcy jako postaci empatycznej, nastawionej na budowanie relacji międzyludzkich i niekoniecznie aspirującej do pozycji eksperckiej, a także stosowaniem językowych „zasłon dymnych”, które znacząco upływają na osłabienie komunikatu, wzmocnienie grzeczności i odejście od orzekania (również na poziomie składniouym przez stosowanie pytań dodanych i zurot ku trybowi przypuszczającemu). W dalszej części artykułu

\footnotetext{
${ }_{10}$ D. Tannen, op. cit.

${ }^{11}$ R. Lakoff, op. cit.; za: Mosty zamiast murów, rozdział Męskie i kobiece style ekspresji, red. J. Stewart, PWN, Warszawa 2014.

${ }^{12}$ C. Edelsky, Question Intonation and Sex Roles, „Language in Society” 1979, z. 8, s. 15-32; za: Mosty zamiast murów, op. cit.
} 
przedstawię, jak te tropy badawcze mają się do rzeczywistości, a konkretniej: do pewnego jej wycinka, jakim jest stworzony przeze mnie mikrokorpus mów motywacyjnych.

\section{Mikrokorpus mów motywacyjnych}

Opis materiału źródłowego należałoby zacząć od doprecyzowania, czym właściwie jest sama mowa motywacyjna. Najogólniej rzecz ujmując, możemy nazwać ją przemówieniem mającym na celu wywarcie upłyuu na odbiorcę i wzmocnienie marki osobistej nadaucy. Wspomniany upłyu ma być, rzecz jasna, motyuujący: do zmian, aktyuności, refleksji. Spektrum tematóu pozostaje bardzo rozległe, a wszystkie możliwe wątki nawiązują do przedmiotu zainteresowań psychologii rozwoju osobistego. Ze względu na silny charakter perswazyjny, dający się zamknąć w przekazie typu „zmień swoje życie”, mowy motywacyjne często są wykorzystywane w biznesie jako środek wzmacniający potencjał zespołów - wtedy głóuny nacisk kładzie się na zuiększenie efektywności pracy.

Wspominałam także o róunież istotnym uymiarze podbudouywania marki osobistej mówcy - rozwinę pokrótce ten wątek. Osoba uygłaszająca mowę motywacyjną najczęściej przekazuje metakomunikat o swojej działalności usługowej: daje próbkę swoich możliwości jako coach, trener, mentor itp. Sytuacja komunikacyjna uygłaszania mowy to jednocześnie ustęp do dalszej uspółpracy, droga do nawiązania relacji z odbiorcami, choć oczywiście może stanowić jednostkowe uydarzenie nieposiadające ciągu dalszego. Warto zwrócić uwagę na konteksty, w których najczęściej spotkamy się z tym gatunkiem wypowiedzi. Mouy motywacyjne słyszymy zazuyczaj na konferencjach dotyczących rozwoju osobistego (mniejszych lub większych, które gromadzą często kilka, a nawet kilkanaście tysięcy osób), popularna stała się również praktyka zamawiania mów na wydarzenia zamknięte dla konkretnych grup docelowych (takich jak np. zespoły handlowców). Istotne dla prowadzenia badań jest to, że wiele z takich wystąpień można zobaczyć i usłyszeć przez internet - mówcy chętnie udostępniają je zaróuno bezpłatnie przez serwis YouTube, jak i płatnie przez własne kanały sprzedażowe.

Na materiał źródłowy wykorzystany w artykule składa się sporządzony przeze mnie mikrokorpus dziesięciu mów motywacyjnych pochodzących właśnie z YouTube’a, w którym zostały zamieszczone legalnie i są bezpłatnie dostępne. Z uwagi na rzetelność analizy starałam się dobrać przemówienia w taki sposób, aby zawierały jak najwięcej cech uspólnych pod uzględem charakterystyki technicznej, poprzestałam natomiast na przyjęciu rozległego podobieństua tematycznego. Nie zausze ujednolicenie okazywało się możliwe - czasem z różnych względów decydowałam się na włączenie mowy niestandardowej. Każdy taki wyjątek znajduje jednak uzasadnienie jako zawierający cechy językowe, które uznałam za relewantne ze względu na cel badań.

Badane mowy motywacyjne opisałam w tabeli, którą opatrzyłam dłuższym komentarzem dotyczącym przyjętych wyznaczników doboru tekstów. 


\begin{tabular}{|c|c|c|c|c|c|c|}
\hline 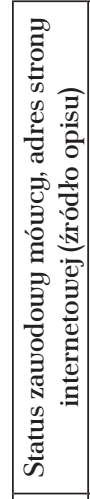 & 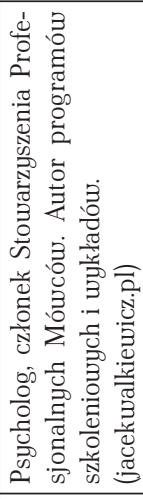 & 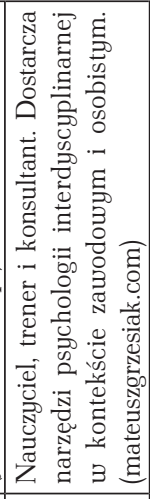 & 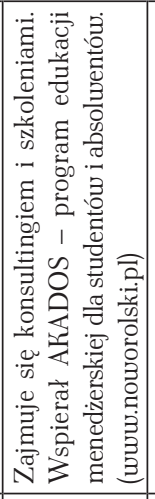 & 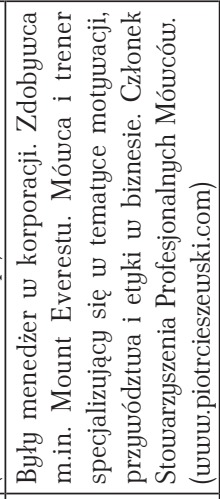 & 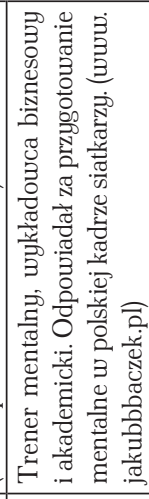 & 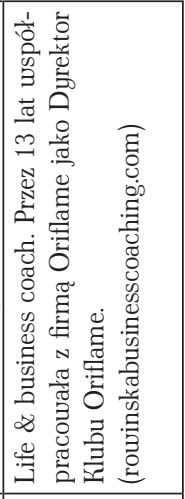 \\
\hline 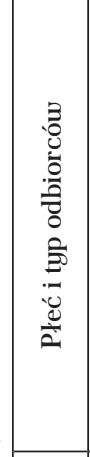 & 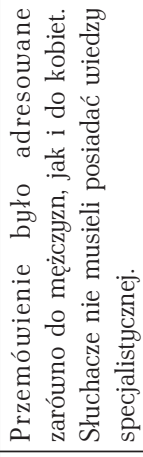 & 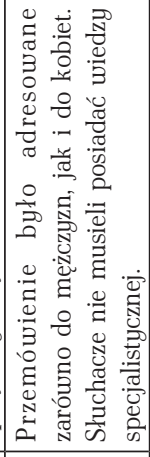 & 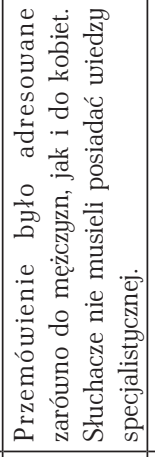 & 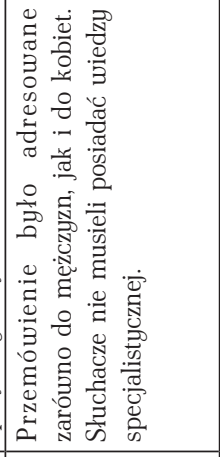 & 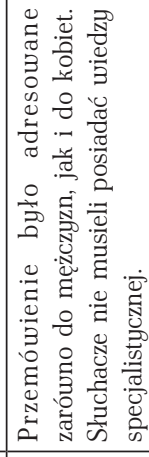 & 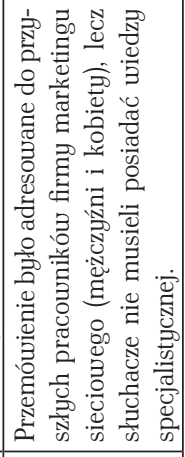 \\
\hline 胥 & 궁 & $\underset{\ddot{i}}{\ddot{H}}$ & $\begin{array}{l}\stackrel{\leftrightarrow}{*} \\
\stackrel{\sim}{*}\end{array}$ & ळ̊. & $\stackrel{\stackrel{L}{\oplus}}{\stackrel{\Theta}{\Perp}}$ & $\begin{array}{l}\text { ஓे } \\
\text { ळें }\end{array}$ \\
\hline 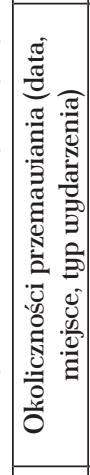 & 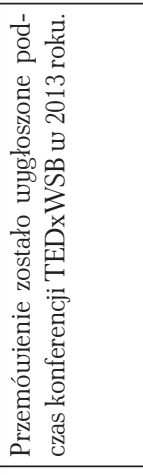 & 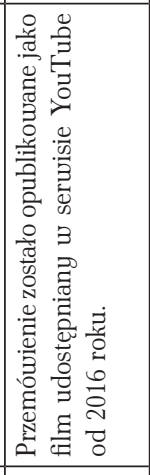 & 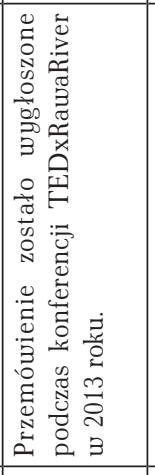 & 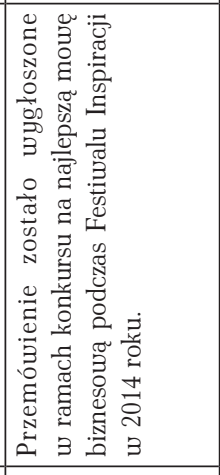 & 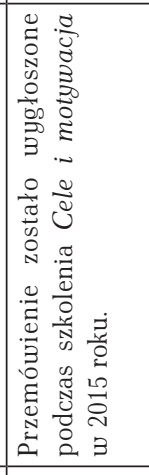 & 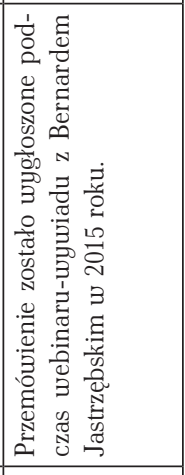 \\
\hline 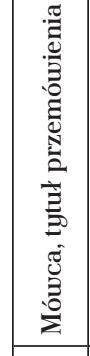 & 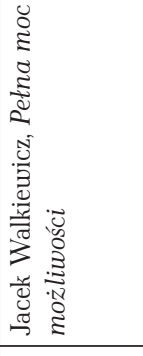 & 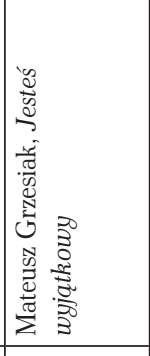 & 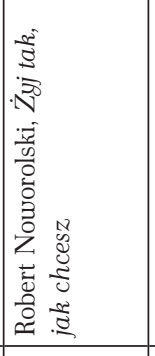 & 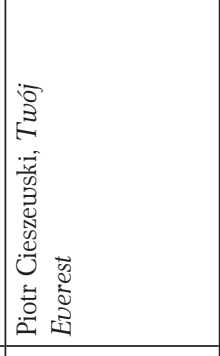 & 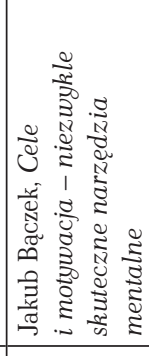 & 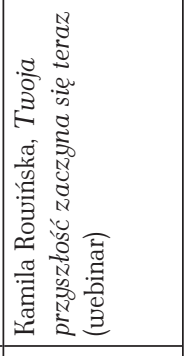 \\
\hline$\stackrel{2}{9}$ & - & $\sim$ & $\dot{m}$ & $+\dot{r}$ & ம் & 6. \\
\hline
\end{tabular}


Różnice w stylach komunikacyjnych kobiet i mężczyzn

\begin{tabular}{|c|c|c|c|c|}
\hline 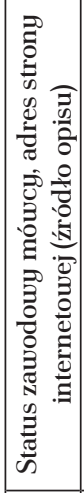 & 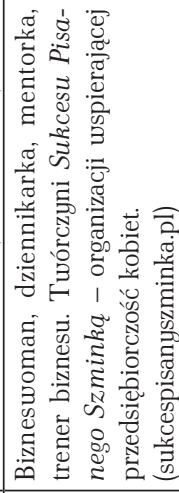 & 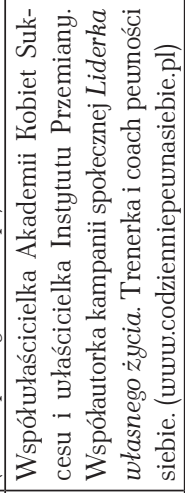 & 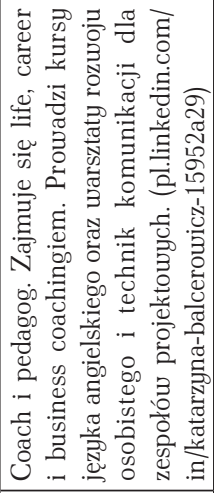 & 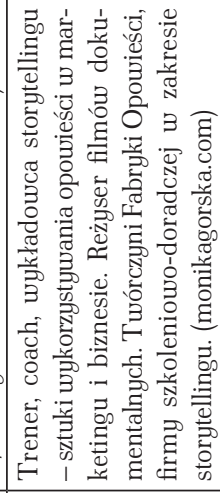 \\
\hline 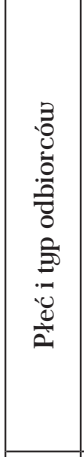 & 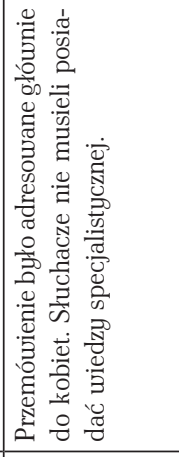 & 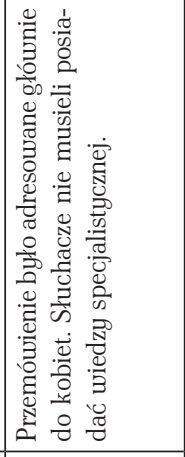 & 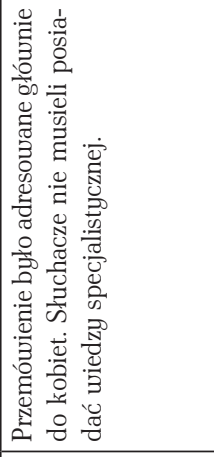 & 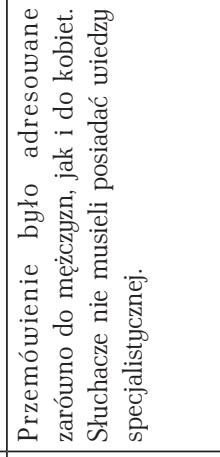 \\
\hline U & 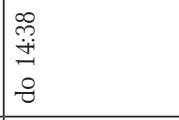 & 官 & 吕 & 㐫 \\
\hline 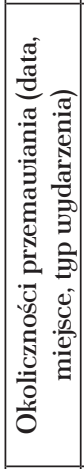 & 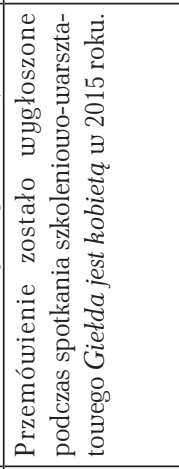 & 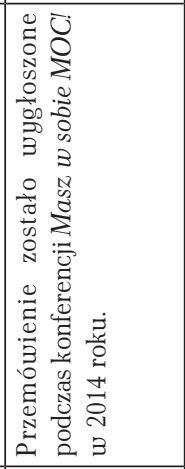 & 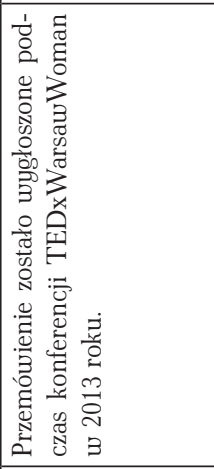 & 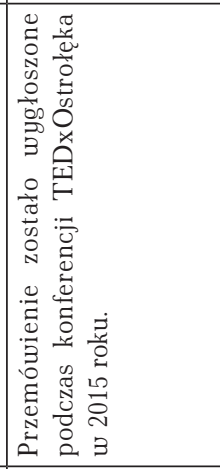 \\
\hline 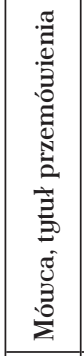 & 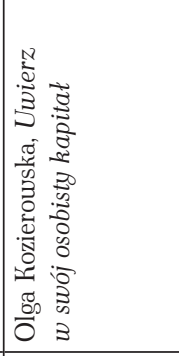 & 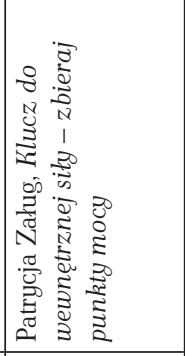 & 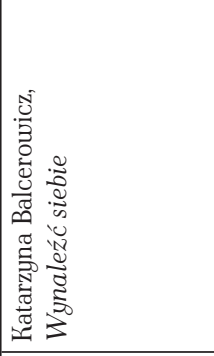 & 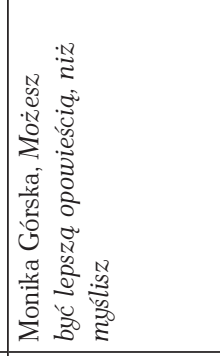 \\
\hline$\dot{1}$ & $\sim$ & $\infty$ & $\sigma^{\circ}$ & $\stackrel{-}{-1}$ \\
\hline
\end{tabular}


- Okoliczności przemawiania (data, miejsce, typ uydarzenia). Analizowane mowy były wygłaszane podczas dużych konferencji motywacyjnych, co wiązało się z formą wykładu przed publicznością. Założyłam, że do korpusu włączę wyłącznie przemówienia uygłoszone po roku 2011, ponieważ rynek rozwoju osobistego rozwija się na tyle dynamicznie, że w mowach z lat wcześniejszych zapewne widoczne byłoby nieustabilizowanie dziedziny na rynku polskim i brak sprawdzonych praktyk.

Dopuściłam trzy wyjątki od tego założenia.

- Mowa Mateusza Grzesiaka została uyłącznie nagrana - nie uygłoszono jej na żywo przed publicznością, jest to jednak jedyny dostępny darmowo materiał tego mówcy, który uykazuje podobieństwo z innymi tekstami korpusowymi. Obecność uskazanego przemówienia uważam za niezbędną, ponieważ Mateusz Grzesiak zajmuje w Polsce bardzo wysoką pozycję na rynku rozwoju osobistego.

- Mowa Kamili Rowińskiej również nie była wygłaszana przed publicznością, choć w tym przypadku mamy do czynienia z nagraniem na żywo, co do pewnego stopnia może odwzorowywać uystąpienie konferencyjne. Przemówienie Kamili Rouińskiej, podobnie jak Mateusza Grzesiaka, powinno znaleźć się w korpusie ze uzględu na popularność i pozycję rynkową tej ekspertki.

- Mowa Jakuba Bączka stanowiła część szkolenia Życie petne pasji, zdecydowałam się jednak ułączyć przemówienie do korpusu, ponieważ Bączek również należy do grona najpopularniejszych polskich specjalistów w dziedzinie rozwoju osobistego.

- Czas trwania przemówienia. Aby móc poróunywać przemówienia ze względu na ich budowę formalną, wybrałam mowy o podobnej długości, czyli trwające nie krócej niż 10 minut i nie dłużej niż 20 minut. Wyjątkami od tej reguły są przemówienia Mateusza Grzesiaka (ok. 5 minut) i Kamili Rowińskiej (ok. 30 minut), na co miały wpływ przesłanki, o których wspominałam wcześniej.

- Płeć mówcy. Moim celem było zróunoważenie korpusu ze uzględu na płeć nadawcy, dlatego ułączyłam do niego pięć mów uygłaszanych przez mężczyzn oraz pięć mów uygłaszanych przez kobiety. Konsekwencją tego założenia stało się odejście od ujednolicenia płciowego odbiorców. Podczas gromadzenia materiału źródłowego zauważyłam, że kobiety zajmujące się life coachingiem prawie zawsze uystępują głównie przed słuchaczkami, dlatego też w korpusie znalazły się tylko dwa wystąpienia kierowane do przedstawicieli obyduu płci (Kamila Rowińska, Monika Górska). Co ciekawe, mężczyźni uygłaszający przemówienia motywacyjne prawie nigdy nie kierują swojego przekazu wyłącznie do panów. Wyjątkami są konferencje i kursy dotyczące uwodzenia kobiet, lecz ze względu na zbyt duże różnice tematyczne w stosunku do całości materiału nie ułączyłam do korpusu mów tego typu.

- Typ odbiorców. Wszystkie przemówienia korpusoue kierowano do publiczności, która nie musiała posiadać wiedzy specjalistycznej z zakresu life lub business coachingu. Należy przy tym nadmienić, że uczestnicy takich konferencji stanowią najczęściej grupę osób zainteresowanych tematem, a więc $\mathrm{w}$ większości przypadków ich poziom wiedzy dotyczący rozwoju osobistego jest już wysoki. 
- Status zawodouy mówcy. Każda z mów wchodzących w skład mikrokorpusu została uygłoszona przez mówcę, który działa na rynku rozwoju osobistego. Przemawiający deklarują wykonywanie różnych zawodów powiązanych z tą branżą - są coachami, trenerami, mentorami, psychologami, doradcami, konsultantami.

- Tematyka przemówienia. Kuestie najczęściej omawiane u zanalizowanych mowach motywacyjnych to: wyznaczanie celów, spełnianie marzeń, podejmowanie nowych wyzwań, otwartość na zmiany, wzmacnianie siły mentalnej i pewności siebie, rewidowanie wizji świata i samego siebie, podnoszenie skuteczności osobistej, odnoszenie sukcesu w sferze prywatnej i zawodowej.

Przeprowadzając badania, nie korzystałam z wersji mówionej przemówień, ale wyłącznie z transkrypcji, które wykonałam samodzielnie na użytek ich analizy językowej. Zdecydowałam się na korzystanie z wersji pisanej przemówień, a nie mówionej, ponieważ świadomie pomijam oddziaływanie czynników pozawerbalnych na odbiorcę. Zdaję sobie sprawę z tego, że komunikacja niewerbalna odgrywa niezuykle istotną rolę u całości przekazu, postanowiłam jednak, że skupię się jedynie na analizie tekstu dostępnego w wersji zapisu linearnego środków językowych użytych przez mówcę. W swoich badaniach nie biorę też pod uwagę - o ile nie zostały one ujawnione bezpośrednio u tekście wystąpienia - większości indywidualnych cech pozajęzykouych każdego z mówców (uykształcenia, wieku, szczegółów praktyki zawodowej, przebiegu kariery itp.), mimo że dostęp do bardziej rozległego kontekstu zapewne pozwoliłby lepiej scharakteryzować cechy idiolektalne analizowanych wystąpień. W obliczu braku wystarczających danych zakładam jednak, że wiedzę o wizji świata i wartościach ważnych dla każdego z mówców będę czerpać wprost z użytych przez nich środków leksykalnych i gramatycznych.

Podczas moich badań wyznaczyłam trzy główne przedmioty analizy mikrokorpusu: kategorie gramatyczne, zagadnienia leksykalne oraz wizję świata i jej komponenty. W artykule skupię się na tych wnioskach, które dotyczą zróżnicowania płciowego widocznego w stylach komunikacyjnych mówców-kobiet i mówców-mężczyzn. Przyjrzyjmy się zatem, co łączyło, a co odróżniało mouy motywacyjne uygłaszane przez przedstawicieli różnych płci.

\section{Wnioski z analizy materiału źródłowego}

\section{Kategorie gramatyczne}

Wprawdzie analiza oparta na sprawdzeniu funkcjonowania kategorii gramatycznych w tekstach mikrokorpusu nie przyniosła aż tylu wniosków, ile uypływa ze spojrzenia na materiał pod kątem leksykalnym, ale ujawniła kilka ciekawych asymetrii uwarunkowanych płcią nadawców i odbiorców.

W zbadanych mowach widoczna była wysoka frekwencja czasouników w czasie teraźniejszym (co jest zrozumiałe, bo mowy motywacyjne przedstawiają perspektywę 
„zmień się tu i teraz - nie u przeszłości lub przyszłości”) oraz przewaga frekwencyjna form liczby pojedynczej (co również nie dziwi ze uzględu na to, że mówimy o rozwoju osobistym, czyli jednostkowym, indywidualnym dla każdego odbiorcy). Co ciekawe, u kobiet dało się zauważyć tendencję do używania czasu przeszłego, podczas gdy mężczý́ni odnosili się zazwyczaj do teraźniejszości i przyszłości. Osadźmy te wyniki w kontekście: taki stan gramatyczny wynika z tematóu podejmowanych przez mówczynie. Kobiety uyraźnie częściej budowały swoją narrację na kontraście między złą przeszłością a teraźniejszością przynoszącą zmianę i nadzieję na przyszłość. Mężczyźni wybierali inną strategię: zarysouywali teraźniejszość pełną sukcesów oraz snuli ambitne plany. W żeńskich mowach motywacyjnych ważną rolę odgrywa motyu przemiany, skojarzony z konkretnym wydarzeniem - najczęściej negatywnym, bardzo często związanym z chorobą czy niepowodzeniem matrymonialnym. Trudno takie motyuy odnaleźć w mowach męskich: jeśli już pojawiały się wzmianki o przeszłości, to były utrzymane $w$ aurze sukcesu (dotyczyły np. ciężkiej pracy, która później przyniosła świetne rezultaty).

U kobiet narracja pozostawała bardzo mówcocentryczna, stąd niewielki udział liczby mnogiej i 3. osoby gramatycznej, przy czym owa mówcocentryczność dotyczyła opouiadania osobistej historii. Mężczyźni częściej odwoływali się do perspektyuy „ja - oni” lub „my - oni”; w mowach wygłaszanych przez panów znajdziemy więcej użyć liczby mnogiej i 3. osoby gramatycznej.

Ciekawe jest spojrzenie na formy rodzajowe adresowane do odbiorców. Warto tu przypomnieć, że wybrane przeze mnie mowy motywacyjne uygłaszane przez kobiety pochodziły u dużej mierze z uydarzeń, w których uczestniczyło silnie sfeminizowane grono odbiorców - przy czym nie było to celowe założenie badacza, lecz swego rodzaju konieczność, ponieważ jak się okazało, kobiety występowały głównie przed innymi kobietami. Mimo to w mowach żeńskich znajdziemy więcej przykładów form duurodzajowych niż w mowach męskich, adresowanych do audytorium mocno zróżnicowanego płciowo. Kobiety wykazywały zatem większą uważność na strukturę grupy odbiorczej, mężczyźni uybierali natomiast rodzaj męski - wprawdzie domyślny gramatycznie, lecz zapewne też bliższy mentalnie.

\section{Autokreacja nadawcy}

Przy okazji roboczego zdefiniowania mowy motywacyjnej wspomniałam, że stanowi ona również narzędzie autokreacji mówcy. Wygłaszający mowę eksplicytnie i implicytnie wyraża siebie - a raczej przekazuje wizję siebie, którą ma odebrać słuchacz. Porównanie perspektyw, z jakich wypowiadają się mówcy i mówczynie, przynosi więcej cech odmiennych niż wspólnych.

Spoiwem wszystkich mów w mikrokorpusie było projektowanie nadawcy jako twórcy, kreatora, artysty. Mówcy podkreślali własną moc sprawczą i decyzyjność, wskazywali na to, że u życiu to oni wychodzą z inicjatywą, nie obawiając się zmian i konsekwencji. Zarysowała się jednak uyraźna różnica między projektowanym 
nadawcą męskim a projektowanym nadawcą żeńskim, którą romantycznie uyrażam jako opozycję „szkiełko i oko” - „czucie i wiara”.

Mężczyźni do autokreacji wykorzystywali figurę doświadczonego mędrca: podkreślali swoją wiedzę, zdolności analizowania, rozeznanie w prawidłach życia. Kobiety wyraźnie podkreślały natomiast rolę intuicji i uczuć. Ich komunikaty o wiele bardziej odwoływały się do emocji, zmysłów i fizjologii - tak jak na przykład w cytowanym fragmencie:

Po pierusze: zobacz, jak jest. [...] I oddychaj w to. Zrób trzy głębokie oddechy w to, że jak sobie uświadamiam, że okej, teraz jestem na przykład autentyczny na trzy, a teraz na pięć, [...] jak to smakuje [...] Czyli oddychaj w to i rozluźnij się, [...] i możesz sobie powiedzieć z tego właśnie rozluźnionego punktu, w którym jesteś, [...] kiedy przyjąłeś to, przyjęłaś do swojego serca, rozluźniłaś się w tym [...].

Podkreślenie roli uczuciouości znajduje suoje potwierdzenie róunież w kreouanej przez mówców hierarchii wartości.

\section{Wartości istotne w świecie projekłowanym}

Mowy motywacyjne przekazują odbiorcom określoną wizję rzeczywistości, której nieodłączną częścią jest katalog spraw i wartości najważniejszych. Ten zbiór priorytetów życiowych stanowi zresztą coś w rodzaju przepisu na sukces. Mówcy zdają się przekazywać: jeśli będziesz kierować się w życiu właśnie tymi wartościami, osiągniesz wyznaczone cele. Także $w$ tej sferze różnice między mowami męskimi a mowami żeńskimi stają się widoczne, co z kolei wynika z podejmowanych tematów i sposobów autokreacji.

Bez uzględu na płeć dodatnio wartościowana jest sama zmiana. W tekstach odnajdziemy silną obecność metafory kognityunej STAŁOŚĆ TO ŹLE, ZMIENNOŚĆ TO DOBRZE, co wiąże się z oklepanym już stwierdzeniem o wychodzeniu ze strefy komfortu. Bodźcami prowadzącymi do zmiany są: marzenia, talent, oduaga i sprawczość, co podkreślają zaróuno mówcy, jak i mówczynie.

Subtelne różnice uwarunkowane płcią nadawcy dotyczą pojmowania sukcesu. Dla kobiet sukces to przede wszystkim równowaga i samoświadomość. Żeńskie mowy motywacyjne mają w sobie wiele z sinusoidy; to zapisy huśtawki emocji i życiouych zakrętów. To także opis drogi do odnalezienia siebie - stąd tak uyraźne dowartościowanie samoświadomości i uważności, a także suoiste czczenie historii osobistej. Mężczyźni-móucy natomiast, mówiąc o sukcesie, podkreślali wartości zuiązane z pracą: akcentowali rolę wytruałości, konsekwencji, wysiłku, determinacji. Ważna była dla nich skuteczność, która warunkowała wartość danego przedsięwzięcia. Kluczową rolę w męskich mowach motywacyjnych odgrywa osiągnięcie celu - w żeńskich przemówieniach istotniejsza okazuje się sama droga do niego. 


\section{Wskaźniki niepewności u kobiet}

W żeńskich mowach motywacyjnych stanowiących część mikrokorpusu uyraźnie widoczne są wskaźniki niepewności, które przytaczałam wcześniej za Robin Lakoff. Należy zaznaczyć, że różnice stylu komunikacyjnego występowały także między poszczególnymi mówczyniami, jednak całościowo rzecz ujmując, mowy mężczyzn charakteryzowały się dużo większą stanowczością - także na poziomie gramatycznym (wysoka frekuencja krótkich zdań oznajmujących, rzadkie użycia trybu przypuszczającego, stylizowanie opinii na fakty). Wypowiedzi kobiet zawierały wiele słów-przerywników nieniosących żadnych nowych informacji, zdania złożone były z większej liczby elementów, a tryb gramatyczny częściej wychodził poza tryb oznajmujący.

Przytoczmy kilka przykładów leksykalnych uskaźników niepewności (które pogrubiono):

Bo tam w tej sali ci ludzie siedzieli i miało się takie urażenie, że $\mathbf{w}$ ogóle tam się nikt nie wysila. Ja do tej pory jak, jak się, nie wiem, spotykałam się z kimś, rozmawiałam czy nawet $\mathrm{w}$ pracy, że strasznie dużo było w tym wszystkim takich prób udowadniania czegoś, udowadniania swojej wartości, takiego wiecie, starania się, że ja powinnam się tak bardzo starać, nie, i na tych spotkaniach też z ludźmi, że jakieś takie poczucie, że kurczę, że uszyscy jesteśmy w jakiejś roli, że jesteśmy za jakąś maską, że nie możemy tak, tak się spotkać, tak naprawdę się spotkać.

[...] z reguły są to oczywiście wyniki biznesowe, finansowe [...]

I przez te uszystkie lata, kiedy obserwuję ludzi, bardzo dużo rozmawiamy o sukcesie, ponieważ każdy go chce osiągnąć, nie za bardzo się zastanawia, co to jest ten sukces, natomiast większość tych ludzi po prostu myśli o tym, aby ten sukces osiągnąć.

[...] miała ułaśnie pomóc ludziom u odnalezieniu suojej takiej wewnętrznej po prostu pasji

[...] i odpowiedzieć sobie na pytanie, o co mi tak naprawdę w życiu chodzi.

Ci, którzy mają rodzinę i dzieci, i ten cały, że tak powiem, miód życia rodzinnego, spoglądają tęsknym wzrokiem na tych, którzy mają na przykład wycieczki, podróżują z plecakiem i tak dalej, i tak dalej.

Wyraźnie wzmożona frekwencyjność zaimków wskazujących sprawia, że komunikat bardzo traci na sile - przy tylu punktach odniesienia nie wiadomo już, który jest najuażniejszy. Ciągłe użyuanie deiksy, a także innych wskaźników niepewności (utrącenia typu nie, kurczę, wyrażenia kwalifikujące typu w ogóle, $w$ tym wszystkim, nie wiem, jakieś takie, tak naprawdę) pozwala oddalić moment wypowiedzenia słów o większym ładunku zarówno semantycznym, jak i emocjonalnym; umożliwia grę na czas. Użytkounik języka nieco mniej interesujący się językoznawstwem powiedziałby zapewne, że słowa uyraźnie nie chciały przejść mówczyni przez gardło - i sporo byłoby trafnych intuicji $\mathrm{w}$ takim potocznym stwierdzeniu. 
Można zatem postawić następującą tezę: nawet jeżeli mowy żeńskie zostają wzmocnione $u$ jakiś inny sposób - na przykład przez użycie trybu rozkazującego - to na ogół zawierają na tyle dużo leksykalnych uskaźników niepewności, że cały przekaz i tak osłabia się, a treść ginie w natłoku formy. Inaczej jest w przypadku mów męskich, które rzadko zawierają uskaźniki niepeuności, a przez to stają się spójniejsze, wyrazistsze, bardziej stanowcze.

\section{Perspektywy badawcze oraz konsekwencje wniosków dla biznesu (i nie tylko)}

Przedstawiona u artykule analiza różnic między stylami komunikacyjnymi kobiet oraz mężczyzn opierała się na mikrokorpusie mów motywacyjnych - i sądzę, że pieruszym krokiem do pogłębienia badań powinno być uczynienie z owego zbioru makrokorpusu przy jednoczesnej dbałości o jego zróunoważenie. Należy rozbudować bazę tekstów: mowy motywacyjne stanowią dobry materiał źródłouy, lecz potencjalnie nie jedyny adekwatny. Warto będzie sprawdzić, czy podobne tendencje w zróżnicowaniu płciouym pod względem stylu komunikacyjnego występują także w innych rodzajach tekstów z dziedziny rozwoju osobistego, skądinąd bardzo różnorodnej. Zbadać możemy zarówno literaturę popularnonaukową, jak i liczne blogi, artykuły branżowe, newslettery, kursy online - ścieżek jest wiele. Gdybyśmy natomiast poszerzyli zakres tematyczny o teksty z dziedziny zarządzania zasobami ludzkimi, moglibyśmy na przykład pokusić się o określenie lingwistycznych wykładników tak zwanego kobiecego stylu zarządzania. Interesujące jest na przykład spojrzenie w głąb własnego podwórka i zbadanie występowania uskaźników niepeuności w komunikatach mężczyzn oraz kobiet związanych ze środowiskiem akademickim, a w dalszej perspektywie - i o ile to możliwe - scharakteryzowanie stylu komunikacyjnego skorelowanego z płcią naukouca ${ }^{13}$. Pewne jednak, że nie tylko nauce i biznesowi przysłuży się dokładne zbadanie komunikacji międzypłciowej. Zważyuszy na to, że żyjemy w społeczeństwie coraz bardziej heterogenicznym, różnorodnym, dynamicznie się przemieniającym, coraz większą rolę odgrywać będą relacje oparte na mądrym poszanowaniu i wykorzystywaniu różnic, a także na wychwytywaniu punktów wspólnych. Kluczem do usprawniania - nie tylko zresztą stosunków międzyludzkich - jest zaś zrozumienie, a u tym genialnie pomóc może właśnie pochylenie się nad stylami komunikacyjnymi skorelowanymi z płcią.

\footnotetext{
${ }^{13}$ Por. np. A. Zadykowicz, Zróżnicowanie genderowe języka $w$ środowisku akademickim a strategia „gender mainstreaming” w świetle najnowszych badań, „Prace Językoznawcze” 2012, z. 14, s. 273-285.
} 


\section{Bibliografia}

Edelsky C., Question Intonation and Sex Roles, „Language in Society” 1979, z. 8.

Handke K., Język a determinanty ptci, „Język a Kultura” 1994, t. 9.

Handke K., Styl kobiecy we wspótczesnej polszczyźnie kolokwialnej, „Studia z Filologii Polskiej i Słowiańskiej" 1990, t. 26.

Kloch Z., Język i płeć: różne podejścia badawcze, „Pamiętnik Literacki” 2000, z. 1.

Lakoff R., Language and Woman's Place, Harper \& Row, Nowy Jork 1975.

Mosty zamiast murów, rozdział Męskie i kobiece style ekspresji, red. J. Stewart, PWN, Warszawa 2014.

Tannen D., Ty nic nie rozumiesz! Kobieta i mężczyzna w rozmowie, tłum. A. Sylwanowicz, Zysk i S-ka, Poznań 1999.

Zadykowicz A., Zróżnicowanie genderowe języka w środowisku akademickim a strategia „gender mainstreaming” w świetle najnowszych badań, „Prace Językoznawcze” 2012, z. 14.

Mikrokorpus mów motywacyjnych - podstawy transkrypcji (dostęp: 01.09.2018):

Jacek Walkiewicz, Pełna moc możliwości, https://wuw.youtube.com/watch?v=ktjMz7c3ke4

Mateusz Grzesiak, Jesteś wyjątkowy, https://www.youtube.com/watch?v=Omq5alY40Ow

Robert Noworolski, Żyj tak, jak chcesz, https://www.youtube.com/watch?v=mknbLtFhHBM

Piotr Cieszeuski, Twój Everest, https://www.youtube.com/watch?v=hW69S5egsJk

Jakub Bączek, Cele i motywacja - niezwykle skuteczne narzędzia mentalne, https://www. youtube.com/watch?v=BQwhp9WJIOI

Kamila Rowińska, Twoja przyszłość zaczyna się teraz, https://www.youtube.com/ watch?v=bkhExpMmFfA

Olga Kozierouska, Uwierz w swój osobisty kapitat - film obecnie niedostępny, Patrycja Załug, Klucz do wewnętrznej sity - zbieraj punkty mocy, https://www.youtube.com/ watch?v=IfbIXz-yxR4

Katarzyna Balcerowicz, Wynaleźć siebie, https://www.youtube.com/watch?v=uInTTDsM6Bg

Monika Górska, Możesz być lepszą opowieścia, niż myślisz, https://wuw.youtube.com/ watch?v=CsXPECwJAME 